Société d'histoire de la révolution de 1848 et des

révolutions du XIXe siècle

\title{
Introduction. Un bilan de 50 années de recherches sur 1848 et la Seconde République (1948-1997)
}

Francis Démier and Jean-Luc Mayaud

\section{OpenEdition}

\section{Journals}

Electronic version

URL: http://journals.openedition.org/rh19/107

DOI: $10.4000 /$ rh19.107

ISSN: $1777-5329$

\section{Publisher}

La Société de 1848

\section{Printed version}

Date of publication: 1 June 1997

ISSN: 1265-1354

\section{Electronic reference}

Francis Démier and Jean-Luc Mayaud, «Introduction. Un bilan de 50 années de recherches sur 1848 et la Seconde République (1948-1997) », Revue d'histoire du XIXe siècle [Online], 14 | 1997, Online since 10 September 2008, connection on 19 April 2019. URL : http://journals.openedition.org/rh19/107 ; DOI : 10.4000/rh19.107

This text was automatically generated on 19 April 2019

Tous droits réservés 


\title{
Introduction. Un bilan de 50 années de recherches sur 1848 et la Seconde République (1948-1997)
}

\author{
Francis Démier and Jean-Luc Mayaud
}

\section{ABSTRACTS}

Introduction. An assessment of 50 years of studies on 1848 and the Second Republic (1948-1997). The historiography of the 1848 revolution, when considered on a long length of time, has led to the progressive deconstruction of the explanation process developed in the 1950's which is linked to the expansion of studies on the 1789 french Revolution. From a macrohistorical approach of the revolutionary phenomenon, we have moved to a closer study of local realities. The chronological analysis, however, has broaden out to the longer length of the birth of France as a democratic and republican country, the time necessary for the conquest of universal suffrage. The theme of the modernization of the french society has given a direction to the analysis of the social structures and of the "sociabilité". The problem of the various politicizations, according to location, has been brought up in the study of provincial revolution. The social battle of 1848 is now understood as the expression of an original "classconsciousness", the one based on an associative project and on the revolutionary educational method which makes the "bonne République" prevail. With the Second Republic, the progressive middle classes and the wealthy conservative classes have been led to rethink the political control of the "mass".

L'historiographie de la révolution de 1848, considérée sur la longue durée, s'est traduite par la déconstruction progressive d'un schéma explicatif élaboré dans les années 1950, et étroitement lié au développement des études sur la Révolution française. D'une approche macro-historique 
du phénomène révolutionnaire, on a glissé vers l'étude plus fine des réalités locales. En revanche l'analyse chronologique s'est étendue au temps plus long de l'émergence d'une France républicaine et démocratique, temps de la conquête du suffrage universel. Le thème de la modernisation de la société française a orienté l'analyse des structures sociales et de la sociabilité. Le problème de la politisation différenciée selon les régions a été abordé par l'étude de la révolution provinciale. La bataille sociale de 1848 est aujourd'hui comprise comme l'expression d'une " conscience de classe " originale, celle s'articulant autour du projet associatif et d'une pédagogie révolutionnaire faisant prévaloir la "bonne République ". À partir de la Seconde République, bourgeois de progrès et notables conservateurs ont été amenés à profondément repenser le contrôle politique des " masses ".

INDEX

Mots-clés: 1848, Historiographie 